UDC 539.232:546:48:546.22:544.183.26

\author{
M.A. Sozanskyi, P.Yo. Shapoval, R.R. Guminilovych, M.M. Laruk, Yo.Yo. Yatchychyn
}

\title{
SYNTHESIS OF CADMIUM SULFIDE THIN FILMS FROM AN AQUEOUS SOLUTION CONTAINING SODIUM CITRATE
}

\author{
Lviv Polytechnic National University, Lviv, Ukraine
}

\begin{abstract}
The cadmium sulfide (CdS) films were prepared on glass substrates by chemical bath deposition method using aqueous solutions of cadmium chloride, thiourea, sodium citrate (complexing agent) and ammonia (pH regulator). A theoretical calculation of the boundary conditions of the formation of cadmium sulfide and cadmium hydroxide in the citrateammonia system was performed in this work. The composition, structure, optics and morphology of the synthesized CdS semiconductor films were experimentally investigated. The obtained films are two-phase and consist of CdS in both sphalerite and wurtzite modifications. They have a homogeneous solid surface, a practically stoichiometric composition and a narrow interval of the change of optical band gap. The quantumchemical modeling of possible chemism of the $\mathrm{CdS}$ synthesis was performed. According to the results of the calculation, cadmium sulfide is formed from the initial cadmium citrate complex via the formation of several intermediate complexes. An analysis of the obtained experimental results allows finding the relationship between the deposition conditions and properties of the prepared semiconductor films, revealing the advantages of the use of sodium citrate as a complexing agent and determining the expediency of its application.
\end{abstract}

Keywords: cadmium sulfide, semiconductor film, chemical deposition, optical properties, morphology analysis.

DOI: $10.32434 / 0321-4095-2019-123-2-39-46$

\section{Introduction}

Cadmium sulfide $(\mathrm{CdS})$ is one of the most technologically important semiconductor materials of $\mathrm{A}^{\mathrm{II}} \mathrm{B}^{\mathrm{VI}}$ group since it has very suitable properties as a window layer of solar cell applications [1-3]. Chemical bath deposition (CBD) is a popular and effective way to obtain it [4]. This method is based on the synthesis of coatings at temperatures below $373 \mathrm{~K}$ from aqueous solution which consist of the metal salt, complexing agent, chalcogenizer and $\mathrm{pH}$ regulator if necessary.

Previously, the use of trisodium citrate was considered the most successful choice from several complexing agents for deposition of good quality zinc sulfide thin films [5]. Since cadmium is one of the members of zinc subgroup of metals, a synthesis of cadmium sulfide films from an aqueous solution of trisodium citrate can be also carried out. Study of the effect of this complexing agent and deposition duration may be performed, which will allow relating these parameters to the properties of the CdS films in order to obtain further high-quality coatings.

\section{Experimental}

Freshly prepared solutions of cadmium chloride $\left(\mathrm{CdCl}_{2}\right)$, ammonia $\left(\mathrm{NH}_{3}\right)$ as $\mathrm{pH}$ regulator, sodium citrate $\left(\mathrm{Na}_{3} \mathrm{C}_{6} \mathrm{H}_{5} \mathrm{O}_{7}\right)$ as complexing agent and thiourea $\left(\left(\mathrm{NH}_{2}\right)_{2} \mathrm{CS}\right)$ were used for the CBD of CdS films. The working solution was prepared from the sequential addition of these reagents: $10 \mathrm{~mL}$ of $0.1 \mathrm{M} \mathrm{CdCl}_{2}$ solution, $2 \mathrm{~mL}$ of $14.28 \mathrm{M} \mathrm{NH}_{3}$ solution, 2-40 mL of $0.5 \mathrm{M} \mathrm{Na}_{3} \mathrm{C}_{6} \mathrm{H}_{5} \mathrm{O}_{7}$ solution, $138 \mathrm{~mL}$ of distilled water and $10 \mathrm{~mL}$ of $1.0 \mathrm{M}$ $\left(\mathrm{NH}_{2}\right)_{2} \mathrm{CS}$ solution. The total volume of the solution was $200 \mathrm{~mL}$. The final concentrations of compounds in the working solution are given in Table 1. The deposition was carried out for 5-70 $\mathrm{min}$ at a temperature of $343 \mathrm{~K}$. The $\mathrm{pH}$ of working solution was ca. 11.3.

The chemical bath deposition of CdS films was performed on pre-cleaned glass substrates $(24 \times 24$ $\mathrm{mm})$. The deposition was carried out in a glass bath, after which the substrates were removed, washed with distilled water and dried in air.

The possibility of adding $2 \mathrm{~mL}$ of $1.0 \mathrm{M} \mathrm{NaOH}$ 
solution instead of $2 \mathrm{~mL}$ of $14.28 \mathrm{M} \mathrm{NH}_{3}$ solution was considered. In this case, the $\mathrm{pH}$ of working solution was approximately the same, but CdS films were partially separated from the substrates during the synthesis or at the cleaning of coatings with distilled water, which was unpractical.

Table 1

The concentration of the compounds in the working solution for synthesis of CdS films

\begin{tabular}{c|c}
\hline Compound & Concentration, M \\
\hline $\mathrm{CdCl}_{2}$ & 0.005 \\
\hline $\mathrm{NH}_{3}$ & 0.14 \\
\hline $\mathrm{Na}_{3} \mathrm{C}_{6} \mathrm{H}_{5} \mathrm{O}_{7}$ & $0.005-0.10$ \\
\hline$\left(\mathrm{NH}_{2}\right)_{2} \mathrm{CS}$ & 0.05 \\
\hline
\end{tabular}

The synthesized samples of CdS films were yellow in color with a mirror hue. Their adhesion to the glass substrate was strong. The films couldn't be removed by applying mechanical efforts.

The X-ray diffraction analysis of deposited samples was performed using DRON-3.0 diffractometer $\left(\mathrm{CuK}_{\alpha}\right.$ radiation). The primary treatment of film diffractogram for the identification of phases was conducted by using PowderCell program [6]. The unit cell parameters were calculated by the FullProf software package [7]. The investigation of the film surface morphology was carried out using a scanning electron microscope REMMA-102-02 with a microanalysis system. The film thickness was measured using profilometer DEKTAK IIA (SLOAN). The optical transmission spectra of the films were recorded by Xion $500 \ll$ Dr. Lange» spectrophotometer in the wavelength range of 340-900 nm. The optical transmission accuracy was $\pm 0.5 \%$. The optical band gaps $\left(E_{g}\right)$ were determined from $(\alpha \cdot h v)^{2}$ vs. hn dependencies by extrapolation of the linear parts of the $(\alpha \cdot h v)^{2}$ curves to the intersection with the energy axis. The modeling and calculation of geometrical parameters and enthalpies of the formation of CdS synthesis were done by PM7 semi-empirical method using MOPAC 2016 program [available at: http://openmopac.net/] and graphical interface Winmostar version 8.001 [available at: http://winmostar.com].

\section{Results and discussion}

The formation of cadmium complexes with citrate, ammonia and hydroxide are possible during the synthesis of CdS films. In such a system, the minimum concentration of cadmium salt required for the formation of solid $\mathrm{CdS}$ and $\mathrm{Cd}(\mathrm{OH})_{2}$ phases was calculated by the following equations $[8-10]$ :

$$
\begin{aligned}
& \mathrm{pC}_{\mathrm{Cd}^{2+}}^{\min }=\mathrm{pSP}_{\mathrm{CdS}}-\mathrm{p} \alpha_{\mathrm{Cd}^{2+}}-\left(\mathrm{pK}_{\mathrm{H}_{2} \mathrm{~S}}^{1,2}-2 \mathrm{pH}+\right. \\
& \left.+\frac{1}{2} \mathrm{pK}_{\left(\mathrm{NH}_{2}\right)_{2} \mathrm{CS}}+\mathrm{p}\left[\left(\mathrm{NH}_{2}\right)_{2} \mathrm{CS}\right]-\mathrm{p} \frac{\beta_{\mathrm{H}_{2} \mathrm{CN}_{2}}}{\beta_{\mathrm{H}_{2} \mathrm{~S}}}\right) ;
\end{aligned}
$$

$$
\mathrm{pC}_{\mathrm{Cd}^{2+}}^{\min }=\mathrm{pSP}_{\mathrm{Cd}(\mathrm{OH})_{2}}+2 \mathrm{pH}-\mathrm{p} \alpha_{\mathrm{Cd}^{2+}}-\mathrm{pK}_{\mathrm{H}_{2} \mathrm{O}} \text {, }
$$

where $\beta_{\mathrm{H}_{2} \mathrm{~S}}=\left[\mathrm{H}^{+}\right]^{2}+\mathrm{K}_{\mathrm{HS}^{-}}^{1}\left[\mathrm{H}^{+}\right]+\mathrm{K}_{\mathrm{H}_{2} \mathrm{~S}}^{1,2}$;

$$
\beta_{\mathrm{H}_{2} \mathrm{CN}_{2}}=\left[\mathrm{H}^{+}\right]^{2}+\mathrm{K}_{\mathrm{HCN}_{2}^{-}}^{1}\left[\mathrm{H}^{+}\right]+\mathrm{K}_{\mathrm{H}_{2} \mathrm{CN}_{2}}^{1,2} \text {; }
$$

$\mathrm{p}$ is an indicator (negative decimal logarithm); $\mathrm{C}_{\mathrm{Cd}^{2+}}^{\min }$ is the minimum concentration of cadmium ions required to the formation of a solid phase; $\mathrm{SP}_{\mathrm{CdS}}$ is the solubility product of $\mathrm{CdS} ; \mathrm{K}_{\mathrm{H}_{2} \mathrm{~S}}^{1,2}, \mathrm{~K}_{\mathrm{H}_{2} \mathrm{CN}_{2}}^{1,2}$,

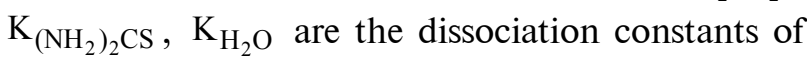
hydrogen sulfide, hydrogen cyanamide, thiourea and water, respectively; $\alpha_{\mathrm{Cd}^{2+}}$ is the molar fraction of the free $\mathrm{Cd}^{2+}$ ions in the solution.

The value of $\alpha_{\mathrm{Cd}^{2+}}$ can be found from the following equation:

$$
\alpha_{\mathrm{Cd}^{2+}}=\frac{1}{1+\frac{[\mathrm{L}]}{\mathrm{K}_{\mathrm{L}}^{1}}+\frac{[\mathrm{L}]^{2}}{\mathrm{~K}_{\mathrm{L}}^{1,2}}+\ldots+\frac{[\mathrm{L}]^{\mathrm{n}}}{\mathrm{K}_{\mathrm{L}}^{1,2, \ldots n}}},
$$

where [L] is the concentration of the free ligand of complexing agent; and $\mathrm{K}_{\mathrm{L}}^{1,2, \ldots \mathrm{n}}$ is the instability constants of the cadmium complexes with citrate, ammonia and hydroxide, respectively.

On the basis of equations (1) and (2), the dependences of the minimum concentration of cadmium salt required for the $\mathrm{CdS}$ and $\mathrm{Cd}(\mathrm{OH})_{2}$ formation at different $\mathrm{pH}$ values of the working solution were plotted (Fig. 1). The calculations were carried out using the following initial values of compound concentrations: $\left[\mathrm{NH}_{3}\right]=0.14 \mathrm{M}$; $\left[\mathrm{Na}_{3} \mathrm{C}_{6} \mathrm{H}_{5} \mathrm{O}_{7}\right]=0.10 \mathrm{M} ;\left[\left(\mathrm{NH}_{2}\right)_{2} \mathrm{CS}\right]=0.05 \mathrm{M}$. The other values of thermodynamic constants used in calculations were taken from the literature data $[10,11]$.

It was impossible in practice to obtain coatings at the minimum calculated concentration $\left(10^{-13} \mathrm{M}\right.$ at $\mathrm{pH}$ 13). The minimum concentration of the initial cadmium salt for the deposition of solid and uniform $\mathrm{CdS}$ thin films was $10^{-3} \mathrm{M}$. Reducing the concentration leads only to slight turbidity without film formation, which was unsuitable. Also by mixing $\mathrm{CdCl}_{2}$ and $\mathrm{NH}_{3}$ at the molar ratio of 1:28 (Table 1), 


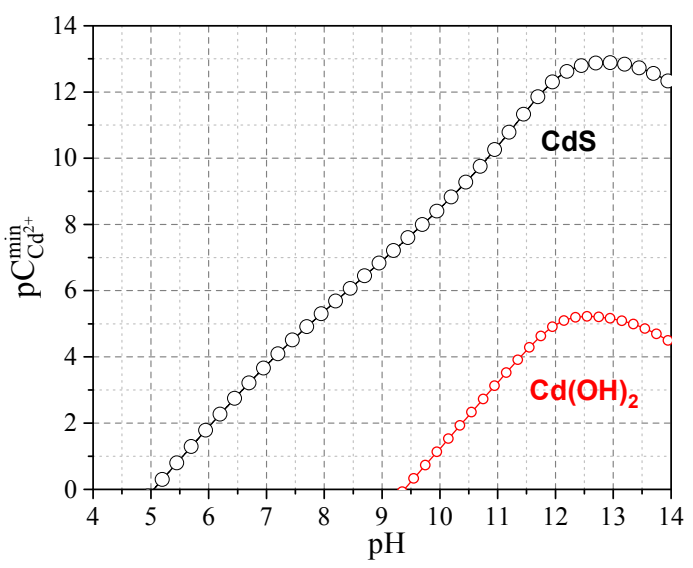

Fig. 1. The boundary conditions of the $\mathrm{CdS}$ and $\mathrm{Cd}(\mathrm{OH})_{2}$ formation in the cadmium-citrate-ammonia system

the white turbidity of $\mathrm{Cd}(\mathrm{OH})_{2}$ was formed instead of $\left[\left(\mathrm{NH}_{3}\right)_{4} \mathrm{Cd}\right]^{2+}$ or $\left[\left(\mathrm{NH}_{3}\right)_{6} \mathrm{Cd}\right]^{2+}$ complex. When $\mathrm{Na}_{3} \mathrm{C}_{6} \mathrm{H}_{5} \mathrm{O}_{7}$ was added to this solution, the turbidity disappeared due to the formation of cadmium citrate complex. In other way, without $\mathrm{Na}_{3} \mathrm{C}_{6} \mathrm{H}_{5} \mathrm{O}_{7}$, only at least 150-fold excess of $\mathrm{NH}_{3}$ over $\mathrm{Cd}^{2+}$ leads to the complete dissolution of $\mathrm{Cd}(\mathrm{OH})_{2}$ and formation of cadmium ammonia complexes. However, we failed to deposit a solid, clear and uniform CdS films in this case.

The phase composition of the synthesized samples was determined by the X-ray diffraction analysis (Fig. 2). We found that the films are twophase in all cases and consist of CdS compound in cubic (structural type $\mathrm{ZnS}$, sphalerite) and hexagonal

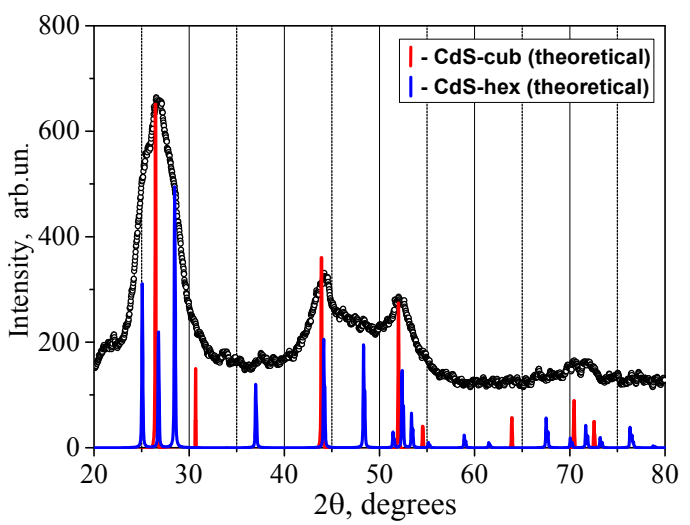

Fig. 2. The experimental X-ray diffraction profile of CdS film

(structural type $\mathrm{ZnO}$, wurtzite) modifications. The parameters of the $\mathrm{CdS}$ unit cells were as follows: $\mathrm{a}=0.5823(4) \mathrm{nm}$ of cubic and $\mathrm{a}=0.4126(1) \mathrm{nm}$, $\mathrm{c}=0.6812(4) \mathrm{nm}$ of hexagonal modification.

The results of the investigation of the surface morphology of CdS films are shown in Figs. 3 and 4. A series of microphotographs indicates that CdS films deposited at small amounts of $\mathrm{Na}_{3} \mathrm{C}_{6} \mathrm{H}_{5} \mathrm{O}_{7}(0.005-$ $0.01 \mathrm{M}$ ) reveal a large amount of precipitate and defects on their surface. There is a deviation from stoichiometric composition as follows from the microanalysis results (Fig. 5). The CdS film was solid, clear and uniform over the whole area with a small number of surface defects at $\mathrm{C}\left(\mathrm{Na}_{3} \mathrm{C}_{6} \mathrm{H}_{5} \mathrm{O}_{7}\right)=0.1 \mathrm{M}$. At this concentration of sodium citrate, the investigation of the effect of deposition duration was carried out. It can be seen that CdS films have the
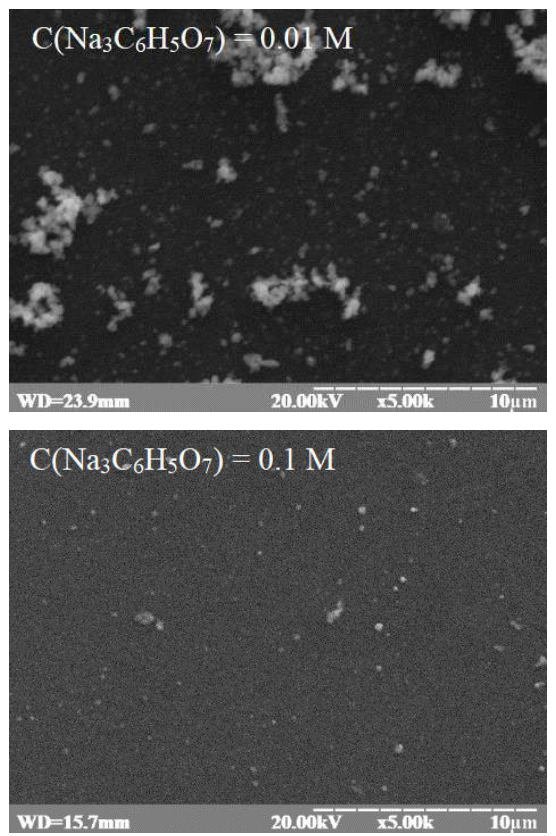

Fig. 3. Surface morphology of CdS films obtained at $60 \mathrm{~min}$ and different concentrations of sodium citrate 

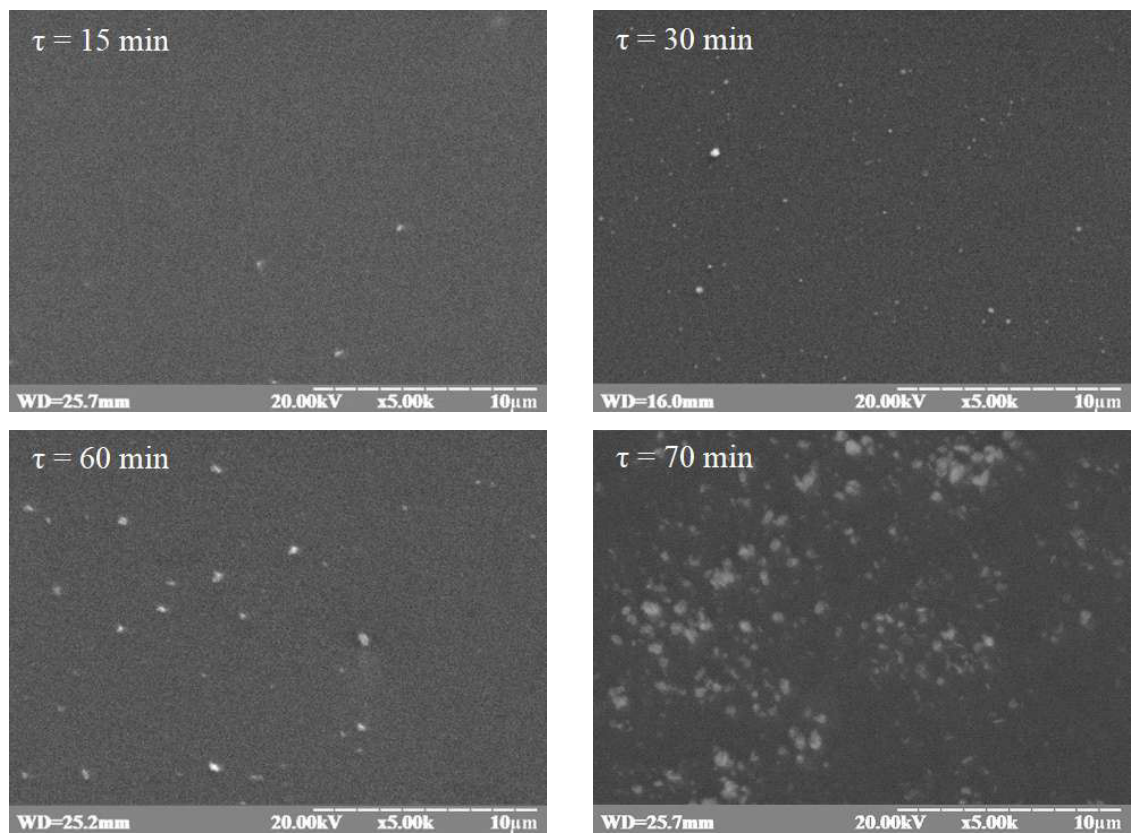

Fig. 4. Surface morphology of CdS films obtained at $\mathrm{C}\left(\mathrm{Na}_{3} \mathrm{C}_{6} \mathrm{H}_{5} \mathrm{O}_{7}\right)=0.1 \mathrm{M}$ and different deposition duration
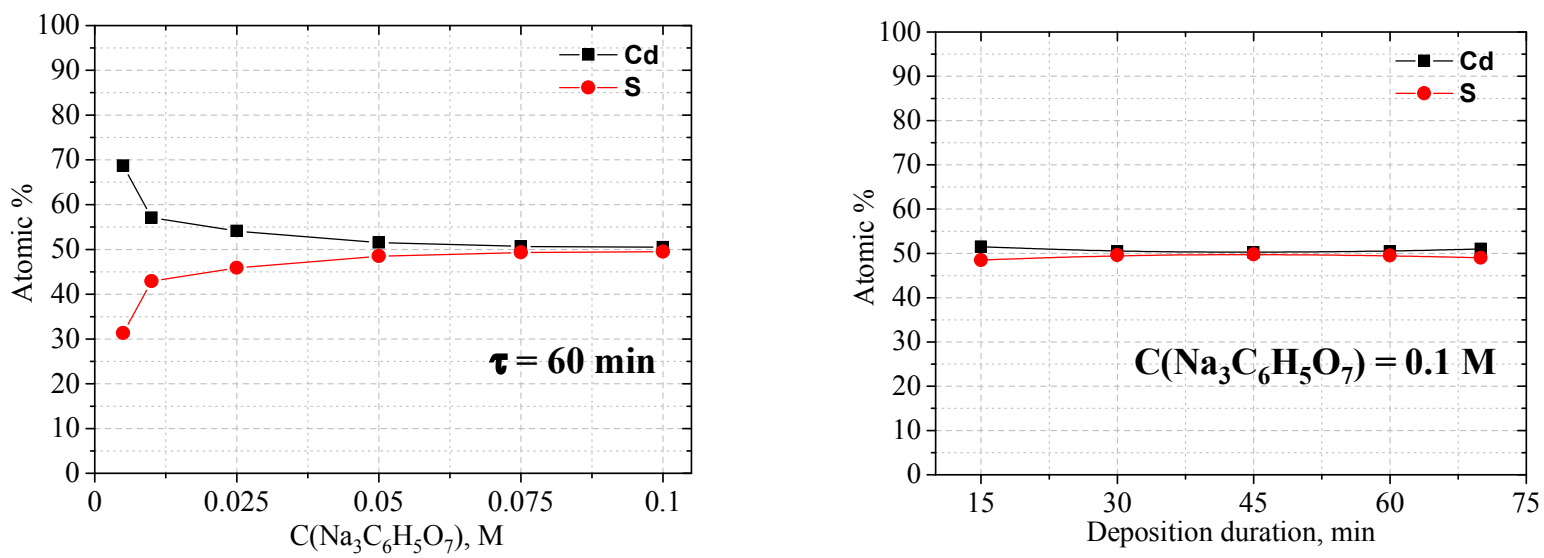

Fig. 5. The atomic composition of CdS films prepared at different concentrations of sodium citrate (left) and different deposition duration (right)

same good quality in 15-60 min region of deposition duration. At longer duration, the coating begins to adsorb the particles of CdS precipitate from the solution. The atomic composition of CdS films is practically stoichiometric with a slight excess of cadmium atoms in whole investigated region of deposition duration.

According to the results of the measurement of CdS films thickness (d), d values are below the minimum measured detection limit $(<10 \mathrm{~nm})$ during first 5-10 min of deposition (Fig. 6). The thickness increases from 12 to $42 \mathrm{~nm}$ at $15-30$ min of deposition. The growth rate is the highest in this interval. The growth rate becomes lower at 35-70 min of deposition and the thickness increases from 45 to $64 \mathrm{~nm}$.

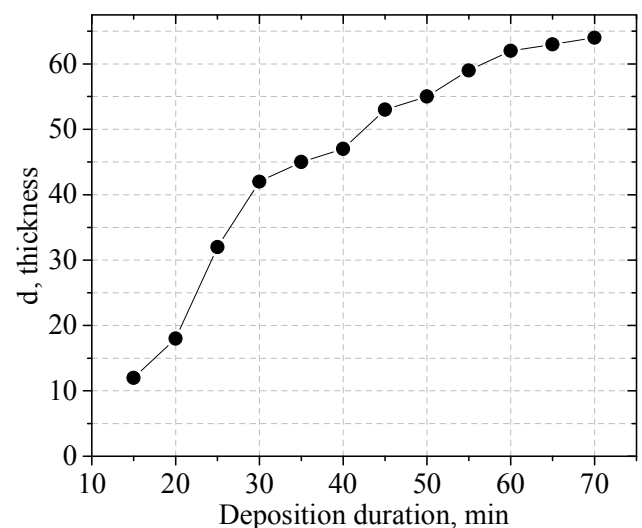

Fig. 6. Thickness of CdS films prepared at different deposition duration 


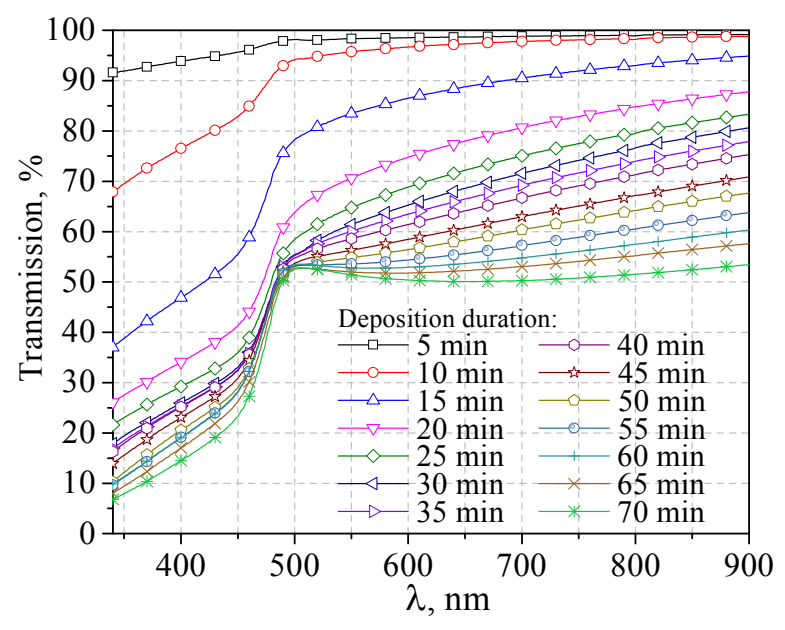

Fig. 7. Spectral dependences of optical transmission of CdS films obtained at different deposition duration

The optical transmission spectra $\mathrm{T}(\lambda)$ of $\mathrm{CdS}$ films obtained at different deposition durations are shown in Fig. 7. The minimum light transmission $\left(\mathrm{T}_{\min }\right)$ at the investigated range of wavelength is observed at $340 \mathrm{~nm}$. An increase in the light transmission can be seen at greater wavelengths. The maximum light transmission $\left(\mathrm{T}_{\max }\right)$ at investigated range of wavelengths located close to $900 \mathrm{~nm}$. In the region of deposition duration of 5-70 min, the values of $\mathrm{T}_{\min }$ and $\mathrm{T}_{\max }$ decrease from $\sim 92 \%$ to $7 \%$ and from $\sim 99 \%$ to $53 \%$, respectively, as a result of increasing the thickness of CdS films. The optical band gap (Fig. 8) numerically decreases from 2.60

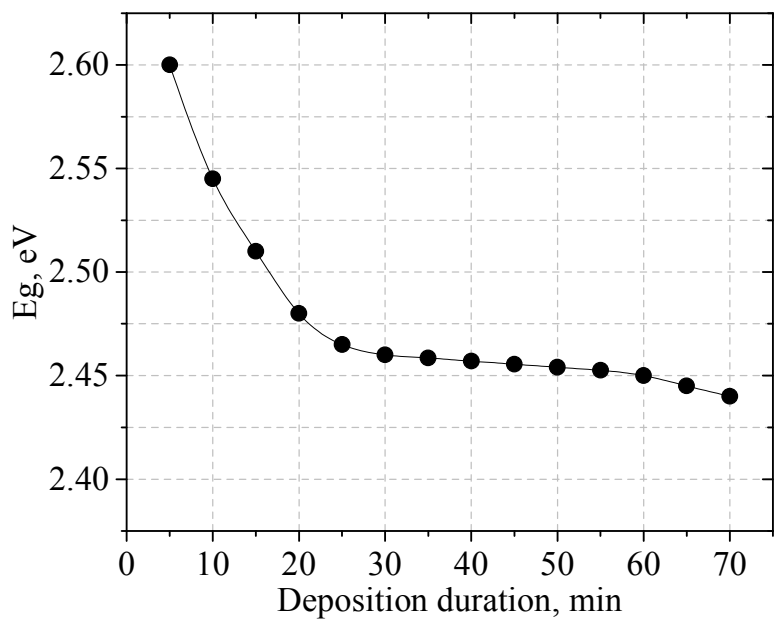

Fig. 8. Optical band gap of CdS films obtained at different deposition duration

to $2.44 \mathrm{eV}$ with increasing the synthesis duration. These values are close to those described elsewhere $[3,12]$. The change of $E_{g}$ can be explained by decreasing the quantum-size effect with increasing the thickness of CdS films.

The formation and further decomposition of an intermediate complex was earlier mentioned as one of possible way of the chemism of CdS formation [4]. The modeling and calculation of geometrical parameters and formation enthalpies were performed (in the conditions of water solution). The geometry of the starting complex of cadmium with citrate was taken from [13]. According to the results of

Table 2

Enthalpy values $\left(\Delta_{f} H\right)$ and interatomic distances at modeled stages of $\mathrm{CdS}$ films synthesis in water solution

\begin{tabular}{c|c|c|c|c|c|c}
\hline Stage & 1 & 2 & 3 & 4 & 5 & 6 \\
\hline$\Delta_{f} \mathrm{H}, \mathrm{kJ} / \mathrm{mol}$ & -2866.63 & -3226.74 & -3266.53 & -3250.09 & -3221.43 & -2934.53 \\
\hline $\mathrm{A}(\mathrm{N})-\mathrm{B}(\mathrm{N})$ & \multicolumn{7}{|c}{ Distance, $\mathrm{nm}$} \\
\hline $\mathrm{Cd}(14)-\mathrm{O}(9)$ & 0.2206 & 0.2285 & 0.2219 & 0.2197 & 0.2168 & 0.516 \\
\hline $\mathrm{Cd}(14)-\mathrm{O}(12)$ & 0.2233 & 0.2292 & 0.2266 & 0.2222 & 0.2175 & 0.5441 \\
\hline $\mathrm{Cd}(14)-\mathrm{O}(13)$ & 0.2351 & 0.2435 & 0.2471 & 0.2561 & 0.2356 & 0.478 \\
\hline $\mathrm{Cd}(14)-\mathrm{O}(28)$ & 0.4000 & 0.2033 & 0.2051 & 0.9943 & 1.0057 & 0.9565 \\
\hline $\mathrm{Cd}(14)-\mathrm{O}(30)$ & 0.4000 & 0.2033 & 0.2028 & 0.2011 & 1.1472 & 1.0960 \\
\hline $\mathrm{Cd}(14)-\mathrm{S}(15)$ & 0.8000 & 0.4000 & 0.4000 & 0.2532 & 0.2272 & 0.2120 \\
\hline $\mathrm{S}(15)-\mathrm{C}(16)$ & 0.1744 & 0.1744 & 0.1750 & 0.1822 & 0.7165 & 0.7165 \\
\hline $\mathrm{C}(16)-\mathrm{N}(17)$ & 0.1353 & 0.1356 & 0.1338 & 0.1382 & 0.1347 & 0.1347 \\
\hline $\mathrm{C}(16)-\mathrm{N}(18)$ & 0.1348 & 0.1352 & 0.1354 & 0.1291 & 0.1166 & 0.1166 \\
\hline $\mathrm{O}(28)-\mathrm{H}(29)$ & 0.0973 & 0.096 & 0.0958 & 0.0966 & 0.0963 & 0.0963 \\
\hline $\mathrm{O}(30)-\mathrm{H}(31)$ & 0.0891 & 0.0959 & 0.0961 & 0.0961 & 0.0963 & 0.0963 \\
\hline $\mathrm{N}(17)-\mathrm{H}(24)$ & 0.1013 & 0.1012 & 0.1092 & 0.1012 & 0.1029 & 0.1025 \\
\hline $\mathrm{N}(17)-\mathrm{H}(25)$ & 0.1016 & 0.1023 & 0.1011 & 0.1011 & 0.1026 & 0.1024 \\
\hline $\mathrm{N}(18)-\mathrm{H}(26)$ & 0.2206 & 0.2285 & 0.2219 & 0.2197 & 0.2168 & 0.5160 \\
\hline $\mathrm{N}(18)-\mathrm{H}(27)$ & 0.2233 & 0.2292 & 0.2266 & 0.2222 & 0.2175 & 0.5441 \\
\hline $\mathrm{O}(28)-\mathrm{H}(24)$ & 0.2351 & 0.2435 & 0.2471 & 0.2561 & 0.2356 & 0.4780 \\
\hline $\mathrm{O}(30)-\mathrm{H}(25)$ & 0.4000 & 0.2033 & 0.2051 & 0.9943 & 1.0057 & 0.9565 \\
\hline
\end{tabular}



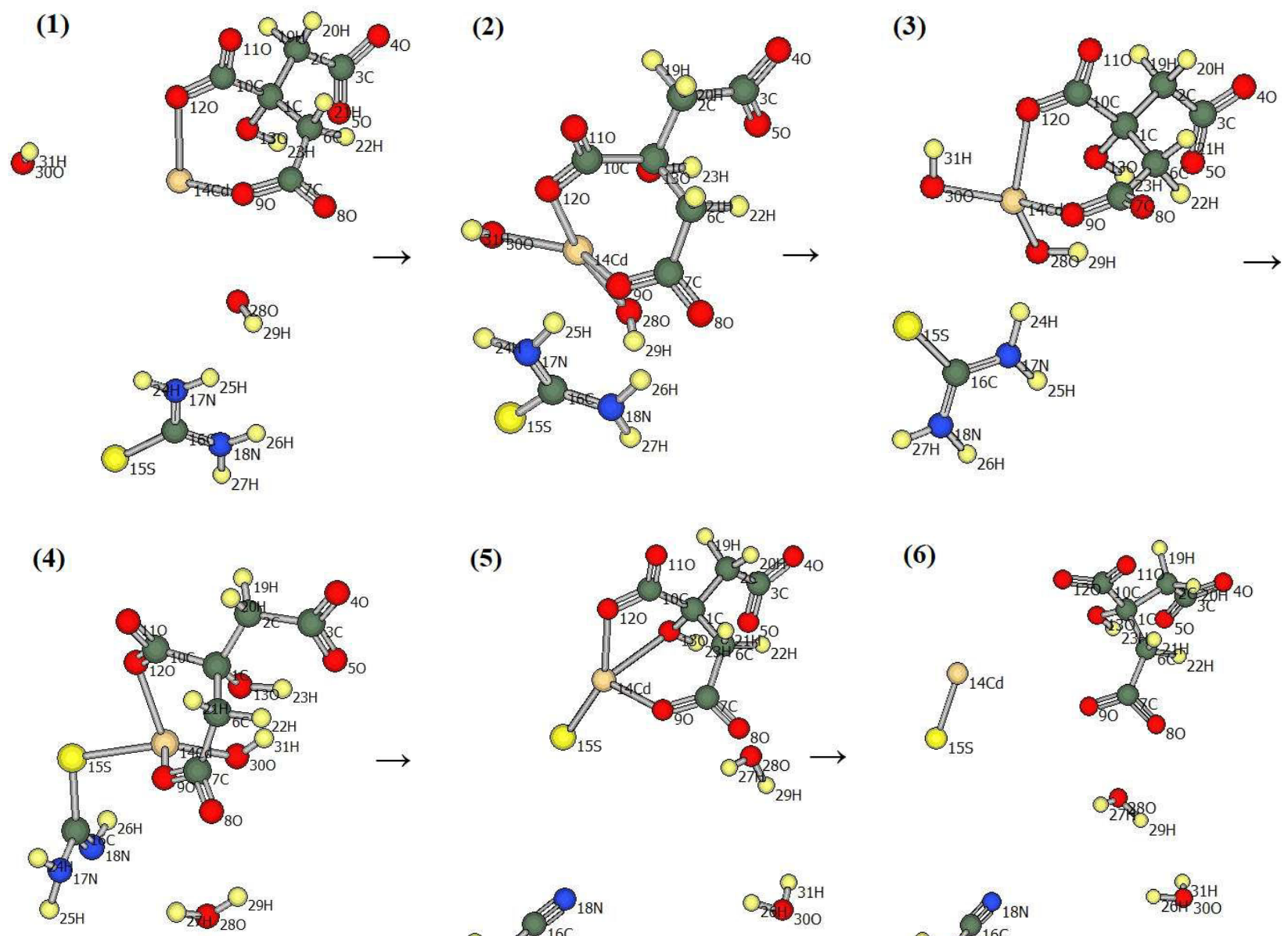

(5)
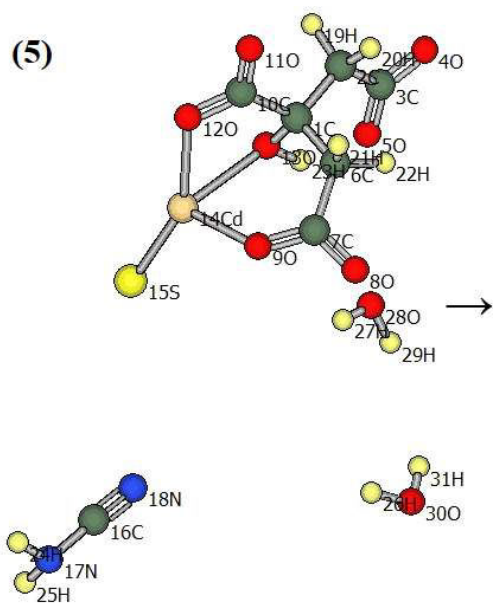

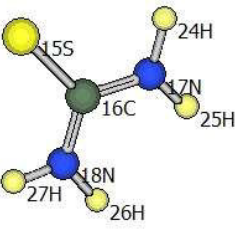

(6)
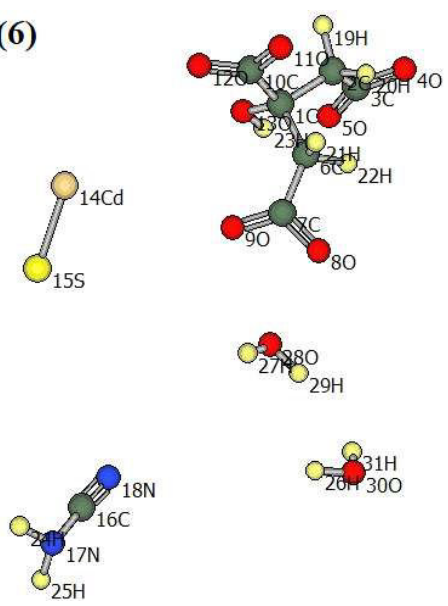

Fig. 9. The simulated stages (1-6) of CdS synthesis

calculations (Fig. 9, Table 2), it was found that the process passes through six stages.

At stages 1 and 2, two $\mathrm{OH}$-groups approach cadmium and two-coordination Cd-complex $\left[\mathrm{Cd} \cdot .\left(\mathrm{C}_{6} \mathrm{H}_{5} \mathrm{O}_{7}\right)\right]^{-}$transforms into four-coordination intermediate complex $\left[(\mathrm{OH})_{2} \cdot . \mathrm{Cd} \cdot .\left(\mathrm{C}_{6} \mathrm{H}_{5} \mathrm{O}_{7}\right)\right]^{3-}$ (the distance of $\mathrm{Cd}(14)-\mathrm{O}(28)$ and $\mathrm{Cd}(14)-\mathrm{O}(30)$ decreases from $0.4000 \mathrm{~nm}$ to $0.2033 \mathrm{~nm}$ ):

$$
\left[\mathrm{Cd} \cdot\left(\mathrm{C}_{6} \mathrm{H}_{5} \mathrm{O}_{7}\right)\right]^{-}+2 \mathrm{OH}^{-} \rightarrow\left[(\mathrm{OH})_{2} \cdot . \mathrm{Cd} \cdot \cdot\left(\mathrm{C}_{6} \mathrm{H}_{5} \mathrm{O}_{7}\right)\right]^{3-} .
$$

Here, the formation enthalpy $\left(\Delta_{\mathrm{f}} \mathrm{H}\right)$ decreases which means that the process is energetically profitable. Then, at stages 3 and 4, the distance between sulfur atom of thiourea and cadmium atom of intermediate complex $(\mathrm{Cd}(14)-\mathrm{S}(15))$ decreases from $0.4000 \mathrm{~nm}$ to $0.2532 \mathrm{~nm}$. As a result, a transitional complex with thiourea $\left(\left[\mathrm{N}_{2} \mathrm{H}_{3} \mathrm{CS} \cdot \mathrm{Cd} \cdot(\mathrm{OH}) \cdot \cdot\left(\mathrm{C}_{6} \mathrm{H}_{5} \mathrm{O}_{7}\right)\right)\right.$ appears $\left(\Delta_{\mathrm{f}} \mathrm{H}\right.$ changes slightly):

$$
\begin{gathered}
{\left[(\mathrm{OH})_{2} \cdot \cdot \mathrm{Cd} \cdot \cdot\left(\mathrm{C}_{6} \mathrm{H}_{5} \mathrm{O}_{7}\right)\right]^{3-}} \\
+\left(\mathrm{NH}_{2}\right)_{2} \mathrm{CS} \rightarrow\left[\mathrm{N}_{2} \mathrm{H}_{3} \mathrm{CS} \cdot \mathrm{Cd} \cdot(\mathrm{OH}) \cdot\left(\mathrm{C}_{6} \mathrm{H}_{5} \mathrm{O}_{7}\right)\right]^{3-} \\
+\mathrm{H}_{2} \mathrm{O} .
\end{gathered}
$$

It is destroyed with the formation of cadmium sulfide, cyanamide, citrate ion and water at last stages 4-6:

$$
\begin{aligned}
& {\left[\mathrm{N}_{2} \mathrm{H}_{3} \mathrm{CS} \cdot \mathrm{Cd} \cdot(\mathrm{OH}) \cdot\left(\mathrm{C}_{6} \mathrm{H}_{5} \mathrm{O}_{7}\right)\right]^{3-} \rightarrow} \\
& \rightarrow \mathrm{CdS} \downarrow+\mathrm{CH}_{2} \mathrm{~N}_{2}+\mathrm{C}_{6} \mathrm{H}_{5} \mathrm{O}_{7}{ }^{3-}+\mathrm{H}_{2} \mathrm{O} .
\end{aligned}
$$

The interatomic distances of former thiourea atoms $\mathrm{S}(15)-\mathrm{C}(16)$ and $\mathrm{N}(18)-\mathrm{H}(26)$ increases from $0.1822 \mathrm{~nm}$ to $0.7165 \mathrm{~nm}$ and from $0.2197 \mathrm{~nm}$ to $0.5160 \mathrm{~nm}$, respectively. When CdS is separated, the distances $\mathrm{Cd}(14)-\mathrm{S}(15)$ decreases to $0.2110 \mathrm{~nm}$. The $\Delta_{\mathrm{f}} \mathrm{H}$ increases at final stage, this indicates that supplying some energy into the system is required. The structure of citrate ligand did not change in the course of 1-6 stages. 


\section{Conclusions}

In this work, an attempt was made to comprehensively consider the synthesis of cadmium sulfide films in order to develop general rules and approaches to control the process of their chemical bath deposition. It has been established that the use of $\mathrm{Na}_{3} \mathrm{C}_{6} \mathrm{H}_{5} \mathrm{O}_{7}$ as a complexing agent in synthesis results in the formation of the two-phase CdS films which are the mix of sphalerite and wurtzite. The effects of $\mathrm{Na}_{3} \mathrm{C}_{6} \mathrm{H}_{5} \mathrm{O}_{7}$ concentration and deposition duration on the morphological properties of $\mathrm{CdS}$ films and their atomic composition were shown. In practical plan, it is advisable to use sodium citrate of highest concentration in the investigated range at 60 min duration, because the films synthesized under such conditions are practically stoichiometric in composition, solid, clear and uniform. Their optical transmission decreases with increasing the deposition duration and it is possible to regulate the optical band gap in the range of 2.60 to $2.44 \mathrm{eV}$. The quantum-chemical modeling of possible chemism process of $\mathrm{CdS}$ synthesis showed that the cadmium sulfide is forming from cadmium citrate complex and thiourea via the formation of two intermediate complexes.

\section{Acknowledgments}

This research was carried out under the project «Thin Film Semiconductor Materials for Photo Sensitive Solar Cells» (State Registration No. 0117U004455).

\section{REFERENCES}

1. Fabrication and characterization of nanowalls $\mathrm{CdS} /$ dye sensitized solar cells / Abdulelah H., Ali B., Mahdi M.A., et al. // Physica E. - 2017. - Vol.90. - P.104-108.

2. Inverted structure hybrid solar cells using CdS thin films / Yavuz N., Yuksel S.A., Karsli A., Gunes S. // Solar Energy Materials \& Solar Cells. - 2013. - Vol.116. - P.224-230.

3. Photosensitivity of $\mathrm{n}-\mathrm{CdS} / \mathrm{p}-\mathrm{CdTe}$ heterojunctions obtained by chemical surface deposition of CdS / Il'chuk G.A., Kusnezh V.V., Rud' V.Yu., et al. // Semiconductors. - 2010. Vol.44. - No. 3. - P.318-320.

4. Recent status of chemical bath deposited metal chalcogenide and metaloxide thin films / Pawar S.M., Pawar B.S., Kim J.H., et al. // Current Applied Physics. - 2011. - Vol.11. No. 2. - P.117-161.

5. The effect of different complexing agents on the properties of zinc sulfide thin films deposited from aqueous solutions / Shapoval P., Sozanskyi M., Yatchyshyn I., et al. // Chemistry \& Chemical Technology. - 2016. - Vol.10. - No. 3. - P. 317-323.

6. Kraus $W$., Nolze G. POWDER CELL - a program for the representation and manipulation of crystal structure and calculation of the resulting X-ray powder pattern // Journal of Applied Crystallography. - 1996. - Vol.29. - No. 3. - P.301303.

7. Roisnel T., Rodriquez-Carvajal J. WinPLOTR: A Windows tool for powder diffraction pattern analysis // Materials Science Forum. - 2001. - Vol.378-381. - P.118-123.

8. Марков В.Ф., Маскаева Л.Н., Иванов П.Н. Гидрохимическое осаждение пленок сульфидов металлов: моделирование и эксперимент. - Екатеринбург: УрО РАН. - 2006. $-218 \mathrm{c}$.

9. Markov V.F., Maskaeva L.N. Calculating the boundary conditions of the formation of solid-phase metal sulfides and selenides by deposition with thio- and selenourea // Russian Journal of Physical Chemistry A. - 2010. - Vol.84. - No. 8. P.1288-1293.

10. Diagrams of the formation of $\operatorname{In}_{2} \mathrm{~S}_{3}$ and $\mathrm{In}_{2} \mathrm{Se}_{3}$ films on vitroceramic upon precipitation, according to potentiometric titration / Tulenin S.S., Bakhteev S.A., Yusupov R.A., et al. // Russian Journal of Physical Chemistry A. - 2013. - Vol.87. No. 10. - P.1771-1777.

11. Лурье Ю.Ю. Справочник по аналитической химии. - Москва: Химия. - 1989. - 448 с.

12. Growth of thin CdS films on glass substrates via reaction of thiourea with cadmium acetate in aqueous solution / Il'chuk G.A., Kurilo I.V., Kus'nezh V.V., et al. // Inorganic Materials. - 2014. - Vol.50. - No. 8. - P.762-767.

13. Theoretical spectroscopic studies and identification of metal-citrate $(\mathrm{Cd}$ and $\mathrm{Pb})$ complexes by ESI-MS in aqueous solution / Bertoli A.C., Carvalho R., Freitas M.P., et al. // Spectrochimica Acta Part A. - 2015. - Vol.137. - P.271-280.

Received 17.12.2018

\section{СИНТЕЗ ТОНКИХ ПЛІВОК КАДМІЙ СУЛЬФІДУ 3 ВОДНОГО РОЗЧИНУ, ЩО МІСТИТЬ НАТРІЙ ЦИТРАТ}

М.А. Созанський, П.Й. Шаповал, Р.Р. Гумінілович, М.М. Ларук, Й.Й. Ятчишин

Методом хімічного осадження з ванни одержано плівки кадмій сульфіду (CdS) на скляних підкладках з використанням водних розчинів кадмій хлориду, тіосечовини, натрій цитрату як комплексоутворюючого реагенту та аміаку як рН-регулятора. Було здійснено комплексні дослідження, які включають: теоретичний розрахунок граничних умов утворення кадмій сульфіду і кадмій гідроксиду в цитратно-аміачній системі, експериментальне дослідження складу, структури, оптики і морфології синтезованих напівпровідникових плівок $C d S$. Одержані плівки були двофазними та містили сполуку $C d S$ в обох модифікаціях: сфалериту та вюрциту. Вони мають однорідну суцільну поверхню, практично стехіометричний склад та невеликий інтервал зміни оптичної ширини забороненої зони. Виконано квантово-хімічне моделювання можливого хімізму процесу синтезу $C d S$. За результатами розрахунків, сульфід кадмію утворюється з вихідного комплексу цитрату кадмію, пройшовши через утворення декількох проміжних комплексів. Аналіз отриманих експериментальних результатів дозволяє знайти зв'язок між умовами осадження CdS і властивостями одержаних напівпровідникових плівок, виявити переваги викори- 
стання натрій цитрату як комплексоутворюючого реагенту $i$ визначити доцільність його використання.

Ключові слова: кадмій сульфід, напівпровідникові плівки, хімічне осадження, оптичні властивості, аналіз морфології.

\section{SYNTHESIS OF CADMIUM SULFIDE THIN FILMS FROM AN AQUEOUS SOLUTION CONTAINING SODIUM CITRATE}

M.A. Sozanskyi ", P.Yo. Shapoval, R.R. Guminilovych, M.M. Laruk, Yo.Yo. Yatchychyn

Lviv Polytechnic National University, Lviv, Ukraine

*e-mail: martyn.a.sozanskyi@lpnu.ua

The cadmium sulfide (CdS) films were prepared on glass substrates by chemical bath deposition method using aqueous solutions of cadmium chloride, thiourea, sodium citrate (complexing agent) and ammonia ( $\mathrm{pH}$ regulator). A theoretical calculation of the boundary conditions of the formation of cadmium sulfide and cadmium hydroxide in the citrate-ammonia system was performed in this work. The composition, structure, optics and morphology of the synthesized CdS semiconductor films were experimentally investigated. The obtained films are two-phase and consist of CdS in both sphalerite and wurtzite modifications. They have a homogeneous solid surface, a practically stoichiometric composition and a narrow interval of the change of optical band gap. The quantum-chemical modeling of possible chemism of the CdS synthesis was performed. According to the results of the calculation, cadmium sulfide is formed from the initial cadmium citrate complex via the formation of several intermediate complexes. An analysis of the obtained experimental results allows finding the relationship between the deposition conditions and properties of the prepared semiconductor films, revealing the advantages of the use of sodium citrate as a complexing agent and determining the expediency of its application.

Keywords: cadmium sulfide; semiconductor film; chemical deposition; optical properties; morphology analysis.

\section{REFERENCES}

1. Abdulelah H., Ali B., Mahdi M.A., Hassan J.J., Al-Taay H.F., Jennings P. Fabrication and characterization of nanowalls CdS/dye sensitized solar cells. Physica E: Lowdimensional Systems and Nanostructures, 2017, vol. 90, pp. 104108.

2. Yavuz N., Yuksel S.A., Karsli A., Gunes S. Inverted structure hybrid solar cells using CdS thin films. Solar Energy Materials and Solar Cells, 2013, vol. 116, pp. 224-230.

3. Il'chuk G.A., Kusnezh V.V., Rud' V.Yu., Rud'Yu.V., Shapowal P.Yo., Petrus' R.Yu. Photosensitivity of n-CdS/p-CdTe heterojunctions obtained by chemical surface deposition of CdS. Semiconductors, 2010, vol. 44, pp. 318-320.
4. Pawar S.M., Pawar B.S., Kim J.H., Joo O.-S., Lokhande C.D. Recent status of chemical bath deposited metal chalcogenide and metaloxide thin films. Current Applied Physics, 2011, vol. 11, pp. 117-161.

5. Shapoval P., Sozanskyi M., Yatchyshyn I., Kulyk B., Shpotyuk M., Gladyshevskii R. The effect of different complexing agents on the properties of zinc sulfide thin films deposited from aqueous solutions. Chemistry \& Chemical Technology, 2016, vol. 10 , pp. 317-323.

6. Kraus W., Nolze G. POWDER CELL - a program for the representation and manipulation of crystal structure and calculation of the resulting X-ray powder pattern. Journal of Applied Crystallography, 1996, vol. 29, pp. 301-303.

7. Roisnel T., Rodriquez-Carvajal J. WinPLOTR: a Windows tool for powder diffraction pattern analysis. Materials Science Forum, 2001, vol. 378-381, pp. 118-123.

8. Markov V.F., Maskaeva L.N., Ivanov P.N., Gidrokhimicheskoe osazhdenie plenok sul'fidov metallov: modelirovanie i eksperiment [Chemical deposition of films sulfides of metals: simulation and experiment]. UrO RAN, Ekaterinburg, 2006, 218 p. (in Russian).

9. Markov V.F., Maskaeva L.N. Calculating the boundary conditions of the formation of solid-phase metal sulfides and selenides by deposition with thio- and selenourea. Russian Journal of Physical Chemistry A, 2010, vol. 84, pp. 1288-1293.

10. Tulenin S.S., Bakhteev S.A., Yusupov R.A., Maskaeva L.N., Markov V.F. Diagrams of the formation of $\operatorname{In}_{2} \mathrm{~S}_{3}$ and $\operatorname{In}_{2} \mathrm{Se}_{3}$ films on vitroceramic upon precipitation, according to potentiometric titration. Russian Journal of Physical Chemistry A, 2013, vol. 87, pp. 1771-1777.

11. Lur'e Yu.Yu., Spravochnik po analiticheskoi khimii [Handbook on analytical chemistry]. Khimiya, Moscow, 1989. 448 p. (in Russian).

12. Il'chuk G.A., Kurilo I.V., Kus'nezh V.V., Petrus' R.Yu., Shapoval P.I., Guminilovich R.R., Partyka M.V., Tokarev S.V. Growth of thin CdS films on glass substrates via reaction of thiourea with cadmium acetate in aqueous solution. Inorganic Materials, 2014, vol. 50, pp. 762-767.

13. Bertoli A.C., Carvalho R., Freitas M.P., Ramalho T.C., Mancini D.T., Oliveira M.C., de Varennes A., Dias A. Theoretical spectroscopic studies and identification of metal-citrate $(\mathrm{Cd}$ and $\mathrm{Pb}$ ) complexes by ESI-MS in aqueous solution. Spectrochimica Acta Part A: Molecular and Biomolecular Spectroscopy, 2015, vol. 137, pp. 271-280. 